\title{
ACCOUNTING FOR THE FACULTY DIFFERENTIALS IN THE PRODUCTION OF PhD GRADUATES IN A SOUTH AFRICAN UNIVERSITY
}

\author{
M. Tanga* \\ Faculty of Education \\ e-mail: mtanga@ufh.ac.za / http://orcid.org/0000-0002-8016-8094
}

\section{F. Megbowon*}

Faculty of Social Sciences and Humanities

e-mail: fmegbowon@ufh.ac.za / https://orcid.org/0000-0002-1008-1145

\author{
V. Nkonki ${ }^{*}$ \\ Teaching and Learning Centre \\ e-mail: vnkonki@ufh.ac.za / https://orcid.org/0000-0001-6748-0588
}

\section{T. Rulashe*}

Faculty of Management and Commerce

e-mail: trulashe@ufh.ac.za / https://orcid.org/0000-0001-5967-2766

*University of Fort Hare

East London, South Africa

\section{ABSTRACT}

The ability of an institution to graduate students, also known as the throughput rate, is one of the most important means of an institution receiving a grant/ subsidy from the government. This article sought to interrogate the differentials in throughput rates of $\mathrm{PhD}$ graduates per faculty in a selected institution over a period of five years. Framed within the interpretive paradigm, a qualitative approach and a case study design were adopted. A non-probability purposive sample of 30 participants was selected the academic staff within the six faculties that make up the university under investigation. Data was collected through in-depth interviews and document analysis. Interview transcripts were analysed thematically and using the constant comparison technique. The major findings pointed to differentials in $\mathrm{PhD}$ production across faculties as emanating from variations in supervision approaches as reflected in the recruitment and selection of candidates, students' composition, allocation of supervision load, preparation and orientation of candidates, mentoring of both students and junior staff members, as well as monitoring and evaluation of students' progress. The findings also revealed challenges like lack of financial support for students, poor structural set-up of some faculties as well as "positive" discrimination in some faculties. These factors constrained the throughput rates in different faculties differently, resulting 
to a difference in PhD graduate production. It is concluded that there are some quality concerns resulting from the poor processes and procedures as well as the number of graduates from some staff members. It is recommended that the university harmonise its diverse PhD processes and procedures, and enlarge some faculties by creating distinct departments to provide requisite support and interventions to narrow the differentials and improve quality.

Keywords: PhD production, supervision, approaches and methods, graduates, differential

\section{BACKGROUND AND INTRODUCTION}

The apex of qualification is the doctorate degree and it is also regarded as being internationally transferable. Hence, doctorate qualifications in South Africa according to CHE (2018) are generally regarded as equivalent elsewhere across the world. CHE $(2018,5)$ states that the doctorate "requires a candidate to undertake research at the most advanced academic levels, culminating in the submission, assessment and acceptance of a thesis. However, candidates may also present peer-reviewed academic articles and papers, and, in certain fields, creative work ... in partial fulfilment of the research requirements." Therefore, the candidate is required to make a significant and original contribution to his/her field of study. Cloete, Mouton, and Sheppard (2015) pointed out some pertinent doctorate qualities and include the quality of the candidate at entry, the quality of the doctorate programme, the quality of the supervisor, the quality of the doctoral graduate at exit level, the quality of the thesis and any outputs such as journal papers and citations thereof.

Throughput of $\mathrm{PhD}$ students has become a priority of tertiary institutions in recent years due to economic transformation. The Academic of Science in South Africa (ASSAf 2010) released a report on the need for high-level skills for economic development. The report pointed to a broad consensus in the science community that not sufficient numbers of high-quality $\mathrm{PhD}$ degrees are being produced in relation to the developmental needs of the country (ASSAf 2010). This debate of $\mathrm{PhD}$ graduates has prompted the need to increase $\mathrm{PhD}$ graduates in universities. The report added that, there is a need for high-level skills to achieve a developing economy. This therefore calls for the need for effective postgraduate supervision at universities.

Postgraduate supervision refers to the guidance and overseeing of a postgraduate research student by a supervisor to ensure research of high quality and to instil appropriate disciplinary research knowledge (Lessing 2011). De Lange, Pillay, and Chikoko (2011) note that supervision has been identified as an important factor in a successful research process. In order to achieve successful throughput at the postgraduate level ( $\mathrm{PhD}$ graduate), there must be effective supervision. Smith (2010) posits that doctoral research plays a crucial role in driving innovation and growth of nations, and is therefore, a significant contributor to national and international knowledge generation and the research output. In a global scenario, doctoral 
research programmes are considered essential to the development of Higher Education, where universities are the key players in carrying the major responsibility for moulding good researchers at different stages in their career (Vijayakumar and Vijayakumar 2007). For universities to achieve this goal, they need to develop best practices for supervision.

In the Australian context, Albion and Erwee (2011) discuss how dissertation workshops should be designed and delivered to form part of the development of higher education. According to them, three mandatory workshops and three voluntary workshops were organized in Australian universities. These workshops enabled supervisors to complete a professional development course in order to be recognized as accredited supervisors. The mandatory workshops included: policies and procedures related to higher degree research and supervision, developing effective supervisory relationships, and thesis writing. The three voluntary workshops were about guiding doctoral students in writing the dissertation proposal, literature review and communicating with distance Postgraduate students. According to these authors, universities should organize a mandatory workshop where supervisors are trained on high research supervision skills to enable them produce quality doctoral graduates and increase throughput.

In Africa, especially in South Africa, the importance of the doctoral graduates has increased disproportionately in relation to the overall graduate output over the last decade (Cloete et al. 2015). National Planning Commission (NPC) (2012) has prioritised an increase in doctoral output from 1876 in 2012 to 5000 by 2030 (Cloete, Mouton, and Sheppard 2015). This is an indication that there is a desperate need for $\mathrm{PhD}$ graduates in higher education. Most universities have put in place policies to increase alignment of doctoral studies with national needs, and to deepen the quality of doctoral students' support (Maxwell and Smyth 2011).

Figure 1 shows the number of $\mathrm{PhD}$ students registered in the selected university within the past five years. It illustrates the institutional $\mathrm{PhD}$ registration for six faculties from 2014 to 2019 at the selected Higher Education Institution. The Health Sciences faculty being a newly established faculty within the institution has seen the least number of $\mathrm{PhD}$ students registered. It has an overall number of sixty-one students from 2017 to 2019, followed by the law faculty where numbers have fluctuated between ten and thirty students yearly from 2014 to 2019 and has an overall number of students of one hundred and eight. The Education, Management and Commerce, Social Science and Humanities as well as Science and Agriculture Faculties boast high numbers of registered $\mathrm{PhD}$ candidates respectfully with the latter faculty being at the top with one thousand two hundred and forty students registered from 2014 to 2019. It should be remarked that $\mathrm{PhD}$ enrolment targets are proposed by universities and approved as well as monitored by the Department of Higher Education and Training. The approval depends on the 
availability of resources and infrastructure of the university. Similarly, universities allocated $\mathrm{PhD}$ candidates to faculties based on the available resources and infrastructure.

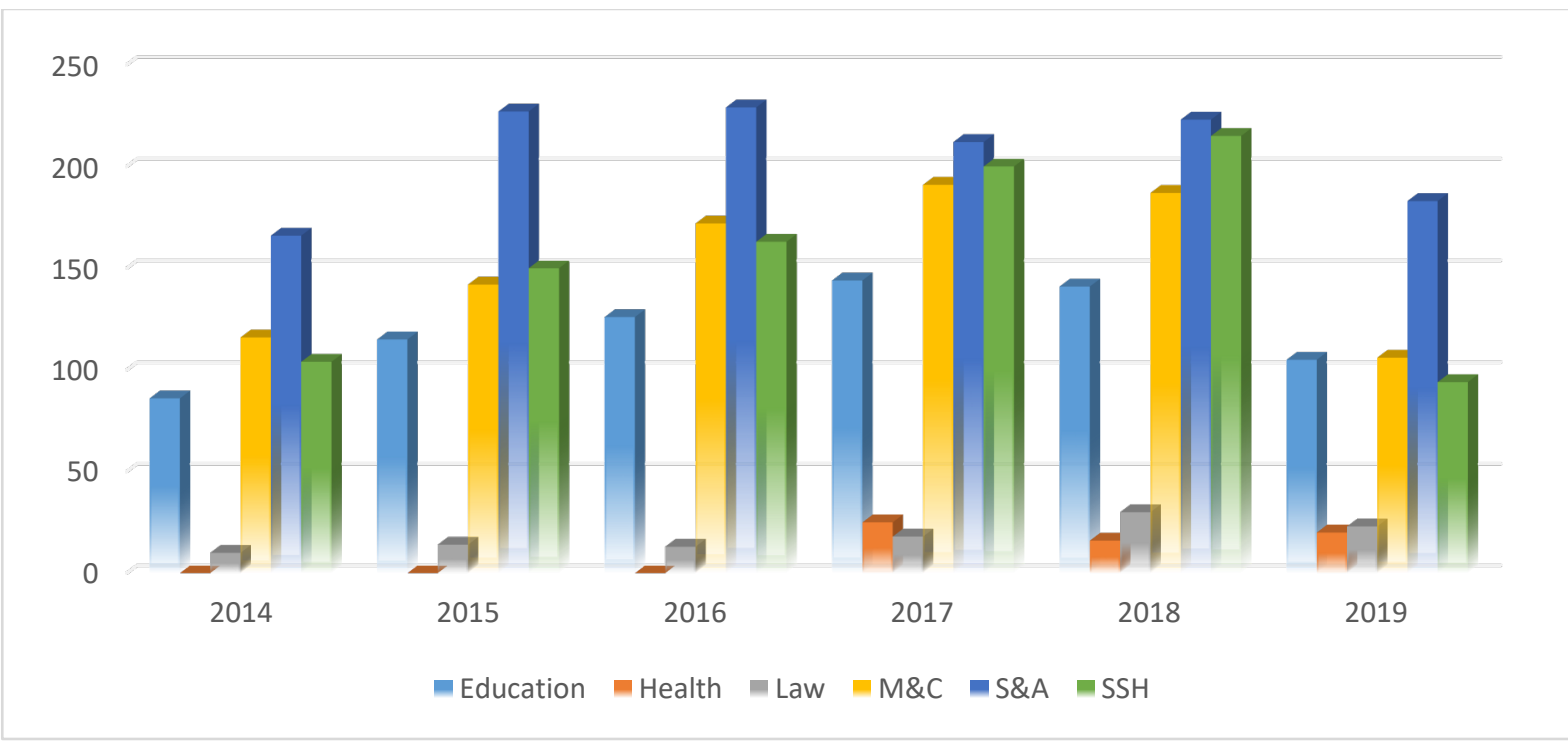

Figure 1: PhD registration - 2014-2019

In most universities in South Africa, doctoral graduates are mostly produced in Social Sciences, and the number produced is five times higher than in other faculties (ASSAf 2010). In this regard, there has been a great stride made to increase throughput of $\mathrm{PhD}$ graduates in some faculties in South African universities. This is seen through the numerous supervisory workshops organized by the university research unit within different faculties to improve research skills

Postgraduate qualifications are increasingly valued in the workplace as knowledge is regarded as a resource for organisations to gain a competitive advantage (Berger 2015) particularly in knowledge-driven economies (Department of Science and Technology (DST) 2008). This perception of intellectual capital currency has brought about credential inflation through the increase in students who enrol for postgraduate studies (Engebretson et al. 2008). As a result, there is increased pressure on institutions and on the supervisor workload due to an influx of students in some faculties in the universities. Engebretson et al. $(2008,10)$ postulate that, in order for supervision to be effective, the quality of supervisors and the quality of $\mathrm{PhD}$ students admitted should be taken into consideration. The implication is that the quality of supervision provided to students should align with best practices. This study explores the faculties faced with this challenge in the selected university, and examines the strategies they employed, for supervision and the quality of their supervisors and students. Table 1 shows $\mathrm{PhD}$ production over a period of five years (2014-2018) across the six faculties of the selected 
university. It shows that the faculty of science and agriculture had persistently surpassed other faculties in PhD production over this period, contrary to the report from (ASSAf 2010), which states that most doctoral degrees are produced in the social sciences - five times higher than other faculties. The main research question is "What accounts for the variation in the production of PhDs in the different faculties of the selected university?" The researchers were motivated by the increasing praising of some faculties by the university management, especially public ceremonies and high-level meetings for successful graduation of $\mathrm{PhD}$ graduates leaving others as though they were not productive. It became apparent for a study to ascertain the reasons for the differential across the different faculties of this university.

Although this article was about the differential across different faculties regarding $\mathrm{PhD}$ production, the qualities specified by Cloete at al. (2015) are also interrogated. As the responsible body for quality assurance of quality of higher education qualifications, not only has the Council on Higher Education (CHE 2018) raised concerns with doctorate qualifications across universities in South Africa but other stakeholders. Some of the concerns include the fact that the increased growth and diversity of doctorates leads to a greater burden on the supervisors and many of them supervising more students as well as supervising outside of their areas of expertise, which is a concern (Cloete et al. 2015, cited from CHE 2018, 9). More so, 60 per cent of doctorate candidates are part-time and this has an impact on the throughput rate. It is argued that South Africa has not increased resources as developed countries thereby presenting contradictory demands for increasing numbers, without substantially increasing resources at the disposal of universities (CHE 2018). Although the projections of doctorate degree holders has not been reached in South Africa, the many concerns raised with respect to doctorate production in South Africa, has led to ASSAf $(2010,6)$ recommending as follows: that there is a need for "Applying strong quality assurance measures to the doctorate to prevent, on the one hand, the irresponsible massification of the degrees in the light of the substantial funding incentives for graduating PhDs; and, on the other hand, to deepen the quality of this final qualification across universities." Thus, ten years after this recommendation, CHE decided to implement it in 2020 by sending a template to universities to evaluate their doctorate programmes and for CHE to undertake site visits in mid-2020 (CHE 2019). Therefore, in gauging the differential production of $\mathrm{PhDs}$ across different faculties, an attempt is made at interrogating some of the qualities mentioned earlier.

The next section of this article is the review of related literature, which ends with a gap that this article intends to fill. This is followed by the research methodology adopted for the collection and analysis of the data. The findings are presented in themes that emerged from the discussions with the participants. This section follows the discussion of the findings in light of 
the literature. Finally, the article ends with the conclusion and recommendations.

\section{LITERATURE REVIEW}

Mertens and Röbken (2013) state that in order to support a continuous flow of PhDs in the private sector, an increased supply of doctorate holders in the traditional sectors of employment is needed. Based on this claim, most universities in the world strive to put systems in place to meet up with these growing demands of PhD graduates. Rasmussen and Borch (2010) argue that universities are heterogeneous organisations and that the support provided to students may vary between the supervisor, research group, department and central university level. According to these writers, the output of $\mathrm{PhD}$ graduates may differ from one faculty to the other depending on the nature of support received by the students during their degree programmes. The assumption here is that at the university level, some faculties are small and may not have equal support and the capacity for student supervision as others.

Studies show that the institutional context can influence research output at most universities. Kenney and Goe (2004) note that the local environment can strongly influence engagement in research through specific history, culture and rules. For instance, some individuals at the university can comply with social norms and follow the behaviours of their peers leading to differences between faculties, departments and research groups concerning how research is encouraged, interpreted and practiced. De Cleyn, Gielen, and Coppens (2014) posit that a significant variation in the actual level of research activities can develop between departments within the same university. According to Griffin and Reddick (2011), faculty members responsible for training and mentoring doctoral students are obligated to foster and model appropriate research behaviour and provide training to enhance such behaviour. For the purpose of this article, research mentoring is understood as the process by which an individual with more research experience works closely with a person with less research experience (research mentee; e.g., doctoral education student) in order to facilitate and increase the level of research competencies and skills (Lambie and Vaccaro 2011).

Some writers state that it is demanding and complex to acquire relevant information specifically for developing a research proposal and completing a successful dissertation. The postulation is that students encounter intellectual logistics and emotional challenges in the process of completing the task. Agency for Higher Education in the UK (QAA 2015) explain that the main resource for helping the students shoulder these challenges is the supervisor. They further advise that the supervisor's strategy focus on student participation in writing groups and other research related workshops, to enhance students' scholarly writing skills. This strategy improves students' research skills and the graduation rate of $\mathrm{PhD}$ students. Arguably, most $\mathrm{PhD}$ 
students are female, older, involved in a professional career, have family responsibilities, and tend to enrol as part time students (Liechty, Liao, and Schull 2009). According to Liechty et al., when students combine studying and conducting research with other responsibilities half of the students fail to complete their degrees because of work conflicts. These scholars observe that balancing the multiple responsibilities may be problematic to the $\mathrm{PhD}$ student and to their supervisors. Studies identify a critical resource for helping doctoral students in coping with the aforementioned challenges. They claim that the best advisor generally, is one who shares the student's topic of interest, has served on dissertation committee several times, and is familiar with research and supervision process before taking on the role of a chair in the supervision process (Engebretson et al. 2008). It is assumed that such a background gives a platform for the supervisor to provide clarity regarding expectations, time management and understanding of the entire research process. The authors say the more experienced professionals the university has, the better the output.

Albion and Erwee (2011) observe that there is a need for training many academics, even those who have been successful supervisors of doctoral students in traditional programmes, in the range of skills appropriate to supervising doctoral students at a distance. This will enable them to build a relationship that fosters trust, transparency and accountability with doctoral students. The assumption here is that, most traditional supervisors are novices in technology, and this affects the supervision process, especially for students studying from a distance. According to these authors, these particular supervisors need help to improve their knowledge on the use of technology, which will improve supervision skills as well. Although many students are being supervised, there is a dearth of literature on the comparison of $\mathrm{PhD}$ production across different faculties of the same university. This article attempts to gauge the differences in $\mathrm{PhD}$ production across different faculties of a selected university in order to shed light on some of the reasons, which might instigate the university to stimulate other faculties to adopt best practices as well as improve the different qualities as stipulated by Cloete et al. (2015). This will increase the overall $\mathrm{PhD}$ throughput rate and boost subsidy from the Department of Higher Education and Training, which however has been seen as the driving force behind the increased growth in $\mathrm{PhD}$ production in South Africa. Most importantly, increased growth in $\mathrm{PhD}$ production will enhance the transformation that we are in dire need of.

\section{RESEARCH METHODOLOGY}

The research employed a qualitative research design within the interpretative paradigm. More specifically, a case study design was utilized, which enhanced the exploration of the diverse 
perspectives of the participants regarding the differences in $\mathrm{PhD}$ production at the university under study. It also enabled the researchers to gather detailed and rich-in context information from the research participants in their natural environments as Strydom (2011) and Creswell (2014) aptly suggest. Purposeful sampling technique was used in the selection of one university in the Eastern Cape Province of South Africa. A sample of 30 was also purposefully selected among the many academic staff members with terminal degrees (doctorate) who were eligible to supervise and were currently supervising doctorate candidates. The sample was selected from the six faculties of the university.

The primary instrument of data collection was a semi-structured interview guide with open and closed-end questions. The questions asked included staff biographical information, staff profiles, supervision arrangements and approaches, challenges, among others. Interviews were conducted at appointed times convenient to the participants in their offices. The interviews took approximately one hour and were audio recorded with the consent of the participants. In addition, document analysis was the other method of data collection used. It involved the exploration of various relevant university documents pertaining the graduation rates of doctorate candidates per faculty, the number of staffs per faculty based on rank etc. A general analytical procedure was used in analysing the qualitative data based on the key themes that emerged from the audiotape recordings, field notes and discussions.

To ensure that findings were credible and trustworthy, triangulation was used to cross check, validate and verify information. The triangulation of sources method was employed through cross verification from a number of sources. Participants came from all the faculties of the university and from different ranks (lecturers, senior lecturers, associate professors and professors, some of whom were deans, deputy deans, directors and head of departments). Varied participants brought different viewpoints to the discussions. This helped to curb bias and enhance the provision of reliable information. The researchers used perspective triangulation through multiple perspectives to examine and interpret the information obtained from the participants. Peer examination was also adopted to ensure the dependability of the data. Trustworthiness, conformity and credibility were ensured through what Kumar (2011) notes as multiple sources, dependability through peer examination, conformability through triangulation of methods, and transferability through a detailed description of the research context. The following ethical principles, as suggested by Babbie (2015), were strictly observed: confidentiality, informed consent, voluntary participation and avoidance of harm. In observing the informed consent principle as suggested by Flick (2018) the researchers explained the purpose and nature of the study to the participants prior to commencement of the interviews. In upholding voluntary participation, the participants were not coerced in any way to participate in the study. 


\section{FINDINGS}

Data presented in this section is made up of the $\mathrm{PhD}$ production within the different faculties in the past five years of the faculties, followed by the different themes that emerged from the outcome of the interviews with the participants.

Table 1: PhD production across faculties at the selected university

\begin{tabular}{|c|c|c|c|c|c|c|}
\hline \multirow{2}{*}{ Faculty } & \multicolumn{5}{|c|}{ Year } & \multirow[t]{2}{*}{ Total } \\
\hline & 2014 & 2015 & 2016 & 2017 & 2018 & \\
\hline Sces \& Agric & 18 & 28 & 34 & 39 & 27 & 146 \\
\hline Mgmt \& Commerce & 18 & 11 & 28 & 19 & 19 & 95 \\
\hline Education & 12 & 13 & 24 & 28 & 10 & 87 \\
\hline $\begin{array}{l}\text { Social Sces \& } \\
\text { Humanities }\end{array}$ & 17 & 10 & 18 & 26 & 15 & 86 \\
\hline Law & 1 & 1 & 5 & 2 & 0 & 9 \\
\hline Health Sces & - & - & - & 6 & 2 & 8 \\
\hline Total & 66 & 63 & 109 & 120 & 73 & 431 \\
\hline
\end{tabular}

Source: University X HEMIS data 2018

Table 1 shows that in the past five years, the faculty of Science and Agriculture has consistently made progress in producing $\mathrm{PhD}$ graduate more than other faculties. This is followed by Management and commerce, Education, Law and Health Sciences faculties being the least. This is questionable when compare to the number of registered students within the different faculties and thus requires this study to account for these great differences. However, as indicated earlier, the Department of Higher Education and Training approves $\mathrm{PhD}$ enrolment targets as well as monitored them for quality purpose. Therefore, no university can enrol the number of $\mathrm{PhD}$ candidates it wishes without the approval of DHET otherwise, the students will not be subsidized.

\section{Theme 1: Supervision approaches}

The first theme that emerged was the supervision approaches which had the following subthemes: recruitment and selection of candidates, student's composition, allocation of supervision load, preparation and orientation of candidates, mentoring of both students and junior staff members, and monitoring and evaluation of the student's progress.

\section{Sub-theme 1: Recruitment, selection and allocation of students}

From the discussions with the participants from the different faculties, it emerged that recruitment and selections of qualified $\mathrm{PhD}$ students was not harmonised. The findings revealed 
that while some faculties such as Science and Agriculture selected $\mathrm{PhD}$ candidates based on submission of mini-proposals, others did not have clear criteria of selection; hence, poorly academic performing students were admitted. Some participants noted that while in some faculties there was competition for limited spaces, other faculties like Law did not even have candidates to make selection from. Few participants noted how some expatriates recruited brilliant $\mathrm{PhD}$ candidates from their home countries to boost their $\mathrm{PhD}$ production. A senior lecturer stated that:

"Many expatriates from science and agriculture recruit many intelligent $\mathrm{PhD}$ students from their home countries and since the business of the students is to undertake their studies, they complete in record time unlike our students who want to take their time. This recruitment from other countries has been motivated by the research incentive paid by the university, which motivates hardworking staff who want additional income."

Most participants indicated that formerly there was no quota allocated to faculties and some supervisors recruited and allocated to themselves as many students as they wished. However, according to one Associate Professor, the limitation to the number of students to be supervised by each supervisor is not adhered to by some supervisors leading to the difference in $\mathrm{PhD}$ production. One Associate Professor indicated that:

\begin{abstract}
"Although there is a policy on the number of students per supervisor, it is adhoc. There is no faculty stipulated method or procedure of allocation in some faculties. Some supervisors select students on their own, agree with them, and continue their supervision. Hence, there is no proper organisation in these faculties despite the Postgraduate Policy document and the new rule restricting more than a certain number of supervisees. Policy sensitization is one of the problems in the university."
\end{abstract}

\title{
Sub-theme 2: Students' composition
}

An interesting sub-theme that came up was the difference in students' composition across the faculties. Some participants stated that faculties where most students were single, foreign, fulltime and male will always surpass those faculties where most $\mathrm{PhD}$ candidates register on parttime basis because they are working, or are married and/or are local with home responsibilities such as attending marriages, fun walks, funerals, and other extended family responsibilities. One professor noted that:

\footnotetext{
"Most of our $\mathrm{PhD}$ students are full-time students who are energetic because you must do practical exercises in laboratories unlike other disciplines where students can successfully register and do their studies through correspondence. In Science, it is not possible. More so, we have concentrated foreign students who are devoted solely to their studies without any distraction. Therefore, we can boost of more $\mathrm{PhD}$ than other faculties of the university."
} 


\section{Sub theme 3: Preparation and orientation of students}

Interviewing the different participants across the faculties, it became apparent that some faculties prepared their $\mathrm{PhD}$ candidates and orientate them on proposal writing within the department, faculty, and library within the university environment than other faculties. Consequently, their students fared better in their studies than those with little or no preparation and orientation. Some participants reported that some supervisors in some faculties had clear guidelines and signed with students' contracts of supervision detailing milestones whereas others were incoherent in the way they prepared their supervision responsibilities. An experienced lecturer noted that:

"My first responsibility towards my $\mathrm{PhD}$ students is to properly orientate them about $\mathrm{PhD}$ studies, challenges, expectations. After this, they have orientation in the department and at the library on how to access the university databases for their studies. All my students signed a contract with me. The contract stipulates my responsibilities and that of the students as well as the milestones and timeframes."

A professor, however, reported that:

"Students are supposed to have orientations organised by the university and not by each staff member. My responsibility is to agree on the topic of the student and supervision begins."

The two scenarios above could yield different results because, to better prepare students on $\mathrm{PhD}$ expectations and the various stakes may enhance a candidate from completing his/her study quicker than those that do not experience such help from their supervisors.

\section{Sub-theme 4: Mentoring of both students and junior staff members}

It was indicated by most participants that it was necessary to mentor students through department seminars where they began the process of learning how to present their work before an audience. While it was reported by all participants from the Faculty of

Science and Agriculture that all their PhD students present their initial proposal ideas at the department before their peers and departmental staff, many participants from other faculties reported individual work with supervisors only. Similarly, some participants indicated that junior staff members who are inexperienced were paired with those that were more experienced or with professors to do the co-supervision. They noted that faculties that undertook such mentorship arrangements got "able hands" to single-handedly supervise PhD students. The result was difference in $\mathrm{PhD}$ production across the faculties. A lecturer noted that: 
"Senior staff members mentor us through co-supervision. It enables the junior staff like us to learn from the senior academics. We also co-publish."

A professor corroborated the above by saying:

"We align junior lecturers with experienced supervisors; hence we work with inexperienced academics so that they can get the exposure to supervise on their own."

Some participants argued that some faculties were able to produce more $\mathrm{PhD}$ graduates because they had more PhD holders with much teaching, research and supervision experience than others. Nonetheless, they suggested that the solution to this is co-supervision with experienced professors.

\section{Sub-theme 5: Monitoring and evaluation of student's progress}

All the participants from the Faculty of Science and Agriculture maintained that monitoring and evaluation of students' progress was through regular seminar presentations of findings, where peers and staff provided input into their academic work. Most participants in the faculty noted that their students regularly presented their proposals to the departments and not necessarily to the faculty higher degrees as in some faculties. Therefore, there were no specific meeting times when students were evaluated by the faculty panel and asked to proceed. However, participants from other faculties indicated that individual supervisors monitored and evaluated the progress of their students. Participants from other faculties noted that they had about four scheduled faculty higher degrees meetings per year, which slowed the progress of their PhD students. A professor and Deputy Dean said:

\footnotetext{
"We, in our faculty, hold regular meetings with all doctoral and masters' students where they present their work at every stage. In this way, we are able to provide valuable inputs to improve the quality of the students' work. Other students and staff also learn from those presenting. We don't also waste time presenting all proposals at the faculty higher degrees committees like other others do."
}

\section{Theme 2: Staff profiles}

Two sub-themes emerged from theme 2, namely: gender variation between faculties and expatriate factor.

\section{Sub-theme 1: Gender difference between faculties}

Many of the participants argued that the difference between the number of females and males 
mattered when it came to successful supervision of PhD students. Some participants mentioned faculties such as education and social sciences having mainly female lecturers who, according to the African traditional culture have triple roles to perform, unlike men. As such, they indicated that they could not be expected to produce as men. A female senior lecturer pointed out that:

"Our faculty has many women unlike some other faculties at this university. Being a patriarchal society, as you know, we have many roles to play; including child bearing and rearing, house chores, taking care of our husbands amongst others. We do not have time to supervise many $\mathrm{PhD}$ students like men who have all the time in the world. So, you can't compare our faculty with many female lecturers to other faculties when it comes to $\mathrm{PhD}$ production.

\section{Sub-theme 2: Expatriate factor}

One of the key factors that contributed significantly to the differential production in $\mathrm{PhD}$ graduates across different faculties was the number of expatriates. Most of the participants in all the faculties reported that the Faculty of Science and Agriculture has a huge number of renowned and experienced expatriate professors than other faculties. As a result, they are able to supervise and graduate more PhD students than other faculties. One professor and Dean noted that:

\footnotetext{
"We have different expatriates in the various departments who are involved in the supervision of many $\mathrm{PhD}$ students in their area of expertise. Some of them are also being assisted in this supervision business by their postdoctoral fellows. In the end, the production is bound to be higher than faculties with few or no expatriates, though there is no faculty without any expatriate."
}

\section{Theme 3: Student support}

There was only one sub-theme that emerged from the theme of student support, funding and financial support.

\section{Subtheme 1: Funding and financial support}

Another critical factor that accounts for the $\mathrm{PhD}$ production differential across faculties at the university under investigation was the amount of financial support provided to $\mathrm{PhD}$ students in the different faculties. According to most participants, science and agriculture students had attractive scholarships and/or financial support from the National Research Foundation, Medical Research Council, Agricultural Research Council as well as other local and national governments. Most respondents said, while these students were "swimming" in money, other students from Education, Management and Commerce were wallowing in poverty and barely surviving. The participants questioned the comparison of the production rate of $\mathrm{PhD}$ graduates 
across faculties. According to a professor who was a Director:

"There is so much attractive funding to science and agriculture students to encourage the study of science which most governments want to see their citizens enrol in. Students in social sciences, humanities, education, management and law are barely managing to study under hard financial conditions. This is what can be termed positive discrimination."

\section{Theme 4: Structural set-up of some faculties}

The fourth theme, structural set-up of faculties had one subtheme, which is smaller and bigger faculties.

\section{Sub-theme 1: Smaller and bigger faculties}

It was indicated by some participants that the smaller or bigger the faculties, the greater the $\mathrm{PhD}$ graduates production. Some participants said it was not advisable to compare the faculties of law and education with science and agriculture, management and commerce, social sciences and humanities, which were merged in the restructuring. While the law and education faculties were not visibly split into different departments, they resembled single departments. They noted that some faculties had many departments and much staff competing to supervise and graduate $\mathrm{PhD}$ students. One professor questioned:

"How on earth can you compare the $\mathrm{PhD}$ production of the faculty of law which is like one department and faculty of health sciences newly established with science and agriculture, social sciences and humanities and management and commerce?"

The structural set-up of the different faculties could have led to differential $\mathrm{PhD}$ production across the different faculties.

\section{DISCUSSION OF FINDINGS}

The recruitment and selection as well as allocation of $\mathrm{PhD}$ students are important components of the processes and procedures involving the proper system and administration of postgraduate students within universities. A proper process leads to a good outcome. However, findings presented in this article showed that these processes and procedures were not uniformly followed across faculties of the university under study. Lecturers in some faculties did not follow the policy guidelines resulting in them having more students than others leading to the differential in PhD graduates production across the faculties. This could lead to poor quality graduates as has been indicated by Cloete et al. (2015). The issue of more students supervised by some lecturers is perceived as a result of research incentives. Literature shows that a good 
$\mathrm{PhD}$ should be well managed with strict guidelines, which must be adhered by all stakeholders (QAA 2015).

One of the key factors affecting the production of $\mathrm{PhD}$ graduates across the different faculties of the university in question was student composition. Supervision of unmarried women, international students, full-time as well as part-time students in the different faculties influences the production of $\mathrm{PhD}$ graduates. Literature corroborates the finding concerning successful graduation of international students and those registered for full-time as well as male students (Andrade 2006). The simple logic is that international students are not distracted by any family responsibilities and as such concentrate on their academic work. According to Liechty et al. (2009), most females and older PhD students tend to enrol as part time students, thereby hindering record-time graduation from their programme. The triple roles of women within most African countries where patriarchy is dominant are well documented and there seems to be little change regarding this (Alliyu 2016). This affects their academic progress negatively.

The success of $\mathrm{PhD}$ students depends on how they are prepared and oriented within the new environment they find themselves, and available facilities of the department, faculty and university. According to Bitzer (2010), $\mathrm{PhD}$ candidates need to be well prepared before embarking on their studies. Other authors have reported that the success of $\mathrm{PhD}$ students relies on how rigorous they are exposed through discussion of the expectations and challenges of undertaking a $\mathrm{PhD}$ programme. Having noticed from the findings that there are variations in the preparation and orientation of $\mathrm{PhD}$ students across different faculties, there are bound to be differences in $\mathrm{PhD}$ graduates production. In addition, the fact that there are differences in terms of seminar presentations, faculty or departmental proposal presentations, as well as monitoring of student's progress; gives rise to differences in $\mathrm{PhD}$ production in the different faculties of the university and the issue of quality comes into play.

Expatriates have been shown to be backbones in some professions including teaching, research and supervision at universities across the world (Lessing 2011). The findings in this article corroborate those of Linden, Ohlin and Brodin (2013) who postulate that expatriates contribute significantly in their various fields of expertise as they devote all their time in doing what they are paid for. This explain why at the university under study, the contribution of expatriates in the production of $\mathrm{PhD}$ graduates in some faculties has also pushed up $\mathrm{PhD}$ production; hence, differentials between faculties. Students' financial soundness is instrumental towards concentration on, and completion of, $\mathrm{PhD}$ studies within record time. Literature has shown that proper funding of doctoral candidates ensures that the completion rate is very high (Wisker, Robinson and Shacham 2007). In this study, faculties prioritised by governments and 
other national funding agencies had greater outputs. Most governments encourage the study of science for scientific and technological advancement as well as innovation that can drive a country's overall development. According to Bitzer (2010), the study of science is given prominence by governments because of the expected dividends from investing in it. This is what some called "positive" discrimination which could have led to differentials in $\mathrm{PhD}$ production and enhanced the quality of the programmes and graduates. The faculty of science and agriculture because of its ability to attract external funding for its students and their numerical strengths have produced highly respected scientists, who upon graduation boast many journal articles and citations, a quality emphasised by Cloete et al. (2015).

A well-structured university into different schools/faculties with specialised departments can lead to competition in terms of research and $\mathrm{PhD}$ graduate production and other related academic responsibilities. The importance of a well-structured system and adherence to policies and procedures cannot be emphasized (ASSAf 2010). Such a good structure at a university could possibly lead to the recruitment of more qualified and experienced staff to operate such sub-structures, such as departments. The findings reveal that there are some faculties which are like "blocks", without distinct departments. In such an instance, there are fewer staff members compared to bigger faculties with many specialized departments. That accounts for differentials between faculties in the production of $\mathrm{PhD}$ graduates.

\section{CONCLUSION AND RECOMMENDATIONS}

The university under investigation is characterised by differences in recruitment, selection and allocation of $\mathrm{PhD}$ students resulting in a haphazard $\mathrm{PhD}$ programme management in some faculties. The situation can be regarded as one that procedures and processes are not harmonised leading to individual faculties and departments, as well as supervisors managing $\mathrm{PhD}$ supervision in different ways. Adherence to policies is also complicated by the lack of a central monitoring system regarding $\mathrm{PhD}$ supervision across faculties. Hence, the concern with the quality of some of the programmes and this perhaps explains the worries of the Council on Higher Education and other stakeholders.

The university is characterised by diverse student population (local and international students). Faculties with more international, unmarried as well as male students outweighed other faculties in $\mathrm{PhD}$ graduate production. Similarly, there was a diverse staff composition (local and expatriates, experienced and non-experienced) leading to differentials in $\mathrm{PhD}$ graduate production across faculties. Given the patriarchal nature of South African society, faculties with women supervisors were bound to have less production of $\mathrm{PhD}$ graduates due to their triple roles. The huge contributions from expatriates, which contributed to differentials in 
$\mathrm{PhD}$ graduate's production cannot be overemphasized. The expatriates bring in the much needed experience and an influx of international students. Related to this is the fact that funding and financial assistance plays a big role in pushing students to certain disciplines, given the poor socio-economic background from which many of them come. This could also point to the quality concern regarding some candidates at the entry level of $\mathrm{PhD}$ studies. Finally, the structural set-up of some faculties leaves a lot to be desired. Some structures handicap faculties' expansion in all directions, be it in terms of recruiting qualified staff and students. All these contributed towards the differentials in PhD production across the different faculties of the university under study.

In the light of the findings and discussion, the following recommended are proffered: First, there is an urgent need for the harmonisation of processes and procedures across faculties of the university to which every supervisor should adhere. This should be followed by a central monitoring system to ensure relevant systems are in place and adhered to. Secondly, given the general cry that most $\mathrm{PhD}$ graduates at the university are international students, the government and university administration should incentivise admission of locals for $\mathrm{PhD}$ programmes and the studying through correspondence or distance with the provision of proper technical facilities. Thirdly, there should be encouragement across all the faculties for more mentoring of junior staff by more experienced colleagues and this should be some incentive for the mentors. In addition, the university should provide funding to students from other faculties not really benefiting from national organisations such as the National Research Foundation, Medical Research Council, Agricultural Research Council amongst others. Some huge faculties that do not operate under different departments are encouraged to split into different specialised departments. This would enhance their structures, as departments would recruit a diverse staff and $\mathrm{PhD}$ students interested in different areas and increase competition among the different faculties. This would lead to an increase in their $\mathrm{PhD}$ graduate production as well as programme and graduates' quality.

\section{REFERENCES}

Academy of Science of South Africa. 2010. The PhD study. An evidence-based study on how to meet the demands of high-level skills in an emerging economy. Consensus Report. Pretoria. September.

ASSAf, see Academy of Science of South Africa.

Agency for Higher Education in the UK (QAA) 2015. Characteristics Statement: Doctoral Degree. London: QAA.

Albion, P. and R. Erwee. 2011. "Preparing for doctoral supervision at a distance: Lessons from experience." In Society for Information Technology \& Teacher Education International Conference, 82-89. Association for the Advancement of Computing in Education (AACE).

Alliyu, N. 2016. "Patriarchy, Women's Triple Roles and Development in Southwest Nigeria." 
International Journal of Arts and Humanities 5(4): 94-110. DOI: doi.org/10.4314/ijah.v5i4.7.

Andrade, M. 2006. "International students in English speaking universities: Adjustment factors." Journal of Research in International Education 5(2): 131-154. DO: 10.1177/147524096065589.

ASSAf see Academy of Science of South Africa.

Babbie, E. R. 2015. The practice of social research. $14^{\text {th }}$ Edition. Canada: Cengage learning.

Berger, R. 2015. "Challenges and strategies in social work and social welfare PhD education: Helping candidates jump through the dissertation hoops." Journal of Teaching in Social Work 35(1-2): $166-178$.

Bitzer, E. 2010. "Postgraduate research supervision: More at stake than research training." Acta Academica Supplementum 1:23-56.

CHE see Council on Higher Education.

Cloete, N., J. M. Mouton, and C. Sheppard. 2015. The doctorate in South Africa: Discourse, data and policies. Cape Town: African Minds.

Council on Higher Education. 2018. Higher Education Qualifications Sub-Framework: Qualification Standard for Doctoral degrees. Pretoria: CHE.

Council on Higher Education. 2019. National Review of Doctoral Degrees offered by Higher Education Institutions in South Africa: Institutional Self-Evaluation Report Template. Pretoria: CHE.

Creswell, J. W. 2014. Research Design: Qualitative and quantitative and Mixed methods Approaches. $4^{\text {th }}$ Edition. Thousand Oaks CA: SAGE.

De Cleyn, S., F. Gielen, and J. Coppens. 2014. "Activating researchers for entrepreneurship: Bridging the gap between research and transfer to society." In University-Industry Interaction Conference, $1-21$.

De Lange, N., G. Pillay, and V. Chikoko. 2011. "Doctoral learning: A case for a cohort model of supervision and support." South African Journal of Education 31(1).

Department of Science and Technology. 2008. Innovation Towards a Knowledge-Based Economy. TenYear Innovation Plan 2008-2018. Pretoria: DST.

DST see Department of Science and Technology.

Engebretson, K., K. Smith, D. McLaughlin, C. Siebold, G. Terret, and E. Ryan. 2008. "The changing reality of research education in Australia and implications for supervision: A review of the literature." Teaching in Higher Education 13(1): 1-15.

Flick, U. 2018. "Triangulation” In The SAGE Handbook of Qualitative Research, ed. N. K. Denzin and Y. S. Lincoln, 444-461. $5^{\text {th }}$ Edition. London and Thousand Oaks, CA: Sage.

Griffin, K. A. and R. J. Reddick. 2011. "Surveillance and sacrifice: Gender differences in the mentoring patterns of Black professors at predominantly White research universities." American Educational Research Journal 48(5): 1032-1057.

Kenney, M. and W. R. Goe. 2004. "The role of social embeddedness in professorial entrepreneurship: A comparison of electrical engineering and computer science at UC Berkeley and Stanford." Research Policy 33(5): 691-707.

Kumar, R. 2011. Research Methodology: A Step-by-Step Guide for Beginners. $3^{\text {rd }}$ Edition. New Delhi: Sage.

Lambie, G. W. and N. Vaccaro. 2011. "Doctoral counsellor education students' levels of research selfefficacy, perceptions of the research training environment, and interest in research." Counsellor Education and Supervision 50(4): 243-258.

Lessing, A. C. 2011. "The role of the supervisor in the supervisory process." South African Journal of Higher Education 25(5): 921-936.

Liechty, J. M., M. Liao, and C. P. Schull. 2009. "Facilitating dissertation completion and success among doctoral students in social work." Journal of Social Work Education 45(3): 481-497. 
Linden, J., M. Ohlin, and E. M. Brodin. 2013. "Mentorship, supervision and learning experience in PhD education." Studies in Higher Education 38(5): 639-662.

Maxwell, T. W. and R. Smyth. 2011. "Higher degree research supervision: From practice toward theory." Higher Education Research and Development 30(2): 219-231.

Mertens, A. and H. Röbken. 2013. "Does a doctoral degree pay off? An empirical analysis of rates of return of German doctorate holders." Higher Education 66(2): 217-231.

National Planning Commission (NPC). 2012. National Development Plan: Vision for 2030. Pretoria: NPC.

Rasmussen, E. and O. J. Borch. 2010. "University capabilities in facilitating entrepreneurship: A longitudinal study of spin-off ventures at mid-range universities." Research Policy 39(5): 602612.

Smith, A. 2010. The theory of moral sentiments. New York: Penguin.

Strydom, H. 2011. Sampling in the quantitative paradigm. Research at Grass Roots. Pretoria: Van Schaik Publishers.

Vijayakumar, J. K. and M. Vijayakumar. 2007. "Importance of doctoral theses and its access: A literature analysis." The Grey Journal 3(2): 67-75.

Wisker, G., G., Robinson, and M. Shacham. 2007. "Postgraduate research success: Communities of practice involving cohorts, guardian supervisors and online communities." Innovation in Education and Teaching International 44(3): 301-320. 